\title{
Evaluation of the Ex-situ Reproductive Capacity of Flemingia faginea (Guill.\& Perr.) Baker, a Species of Medicinal Value in Burkina Faso
}

\begin{abstract}
Assan Gnoumou
Unit of Training and Research in applied sciences and technology, University of Dédougou, P. O. Box 176, Burkina Faso.
\end{abstract}

\begin{abstract}
Raymond Nana
Laboratory of biosciences, department plant biology and physiology, Unit of Training and Research in Life and Earth Sciences, University Joseph KI-ZERBO, 03 P. O. Box 7021, Ouagadougou 03, Burkina Faso.
\end{abstract}

Edith Marie Sylvie Daboué

Seeds technology programme, National centre of Tree Seeds, 01 P. O. Box 2682, Ouagadougou, Burkina Faso.

\begin{abstract}
Amadé Ouédraogo
Laboratory of Plant Biology and Ecology, Unit of Training and Research in Life and Earth Sciences, University Joseph KI-ZERBO, Burkina Faso, 03 P. O. Box 7021, Ouagadougou 03, Burkina Faso
\end{abstract}

Received: November 5, 2020 Accepted: January 8, $2021 \quad$ Published: January 13, 2021 doi:10.5296/jas.v9i1.18198

URL: https://doi.org/10.5296/jas.v9i1.18198

\begin{abstract}
In Burkina Faso, medicinal plants are used mainly by the most vulnerable populations (70\%). This study aims to promote the ex-situ reproduction of Flemingia faginea to make it accessible as a remedy for high blood pressure. Sexual reproduction of Flemingia faginea was carried out to evaluate the effect of 2 pre-germination treatments on the seeds' germination rate. One pre-germination treatement included soaking seeds in tap water for $24 \mathrm{~h}$ (T1), another soaking
\end{abstract}


in boiling water until cooling for $24 \mathrm{~h}$ (T2) while the control experiment did not have any pre-germination treatments (T0). We used seeds from two provenances: North-Sudanian (NS) and South-Sudanian (SS). The germination percentage and mean germination time (MGT) were calculated; additionally, the seedling height, diameter, leaves production were monitored for 2 months. The variance analyses fit to tukeys tests were used to compare the effects of the various treatments on germination rate, mean germination time and seedling growth. The best germination rate was obtained with T0 (96\% NS and 79\% SS). The best mean germination time (MGT) was 7.25 days T2. The best seedling growth was obtained with T0 and $\mathrm{T} 1(\mathrm{P}=0.000)$. As the provenance is concerned, the NS provenance was the best source for germination capacity, for the best seedling growth. A test using seeds from NS combined at T0 conditions provides optimal conditions for production of F. faginea at almost no cost to the local population.

Keywords: Flemingia faginea, sexual reproduction, seedling growth, germination, ex-situ reproduction, Burkina Faso

\section{Introduction}

According to the World Health Organization $80 \%$ of the world's population in developing countries partly or exclusively depend on traditional medicine for their health care. Traditional medicine that is passed from generation to generation (sometimes as a socio-cultural heritage), has existed for many decades in these regions (Compaoré et al., 2018).

In Burkina Faso, traditional medicine remains the main source of primary health care for $70 \%$ of the country's population (Zerbo et al., 2011). Therefore, ethnobotanical studies remain represent a fundamental link between modern scientific knowledge and indigenous knowledge of the local population. Ethnobotanical studies in the country provide information on the use and value of plants such as the inventory and the use of medicinal plants by specific ethnic groups (Ouoba et al., 2006; Bélem and Nana, 2009; Zerbo et al., 2011). Additionally, some studies have been conducted on the aqueous extracts of certain medicinal plants to be used, for the treatment of hypertension (Bélemtougri et al., 2007), as antiseptics, analgesics and diaphoretics (Ouattara-Danté et al., 2003), for the treatment of bacillary dysentery (Millogo-Koné et al., 2007), as anti-nociceptive and anti-inflammatory therapies (Konaté et al., 2018) and as treatment against cervical cancer cell lines (Ouattara et al., 2019).

Furthermore, these researcher studies have also demonstrated the vulnerability and rarity of many medicinal species (Traoré et al., 2011; Koadima, 2008; Ouédraogo, 2006). However, this does not currently bother rural and urban populations. To date, the most domesticated plant species are ornamental plants and crops and the local population has dedicated their efforts to reproduce and improve the variety of domesticated plants to the detriment of medicinal plants. The cultivation of medicinal plants could contribute to their conservation and sustainable management.

In the literature, Flemingea faginea is a medicinal plant that is used to regulate human blood 


\section{Macrothink}

pressure (Dembelé, 1988; Cissé et al., 2016). The prevalence of high blood pressure has been on the increase in Burkina Faso. High blood pressure affects all age groups, however, pregnant women and the elderly living in both villages and cities bear the brunt of this disease. Despite the well-known medicinal value of $F$. faginea; limited research has been focused on its' species in Burkina Faso. F. faginea is mainly found in the southern part of the country in habitats around the banks of a few permanent streams of rivers. Unfortunately, it adaptation to the wetlands may make it vulnerable to global warming and its disappearance from its natural habitat.

The objective of this study was to popularize the ex-situ reproduction of $F$. faginea and make it accessible as a remedy for high blood pressure by, i) assessing the regeneration capacity of its' seeds and, ii) to determining the growth development parameters of its' young plants.

\section{Materials and Methods}

Geographical location of seed collection sites

The seeds of Flemingia faginea were collected from three sites located in two phytogeographical climatic regions of Burkina Faso, i.e. Ouo and Dougoumato located in the south-Sudanian climate and National Park of Kaboré Tambi (PNKT) located in a north-Sudanian climate (Fontès and Guinko, 1995). Figure 1 below shows the location of the seed collection and testing sites.

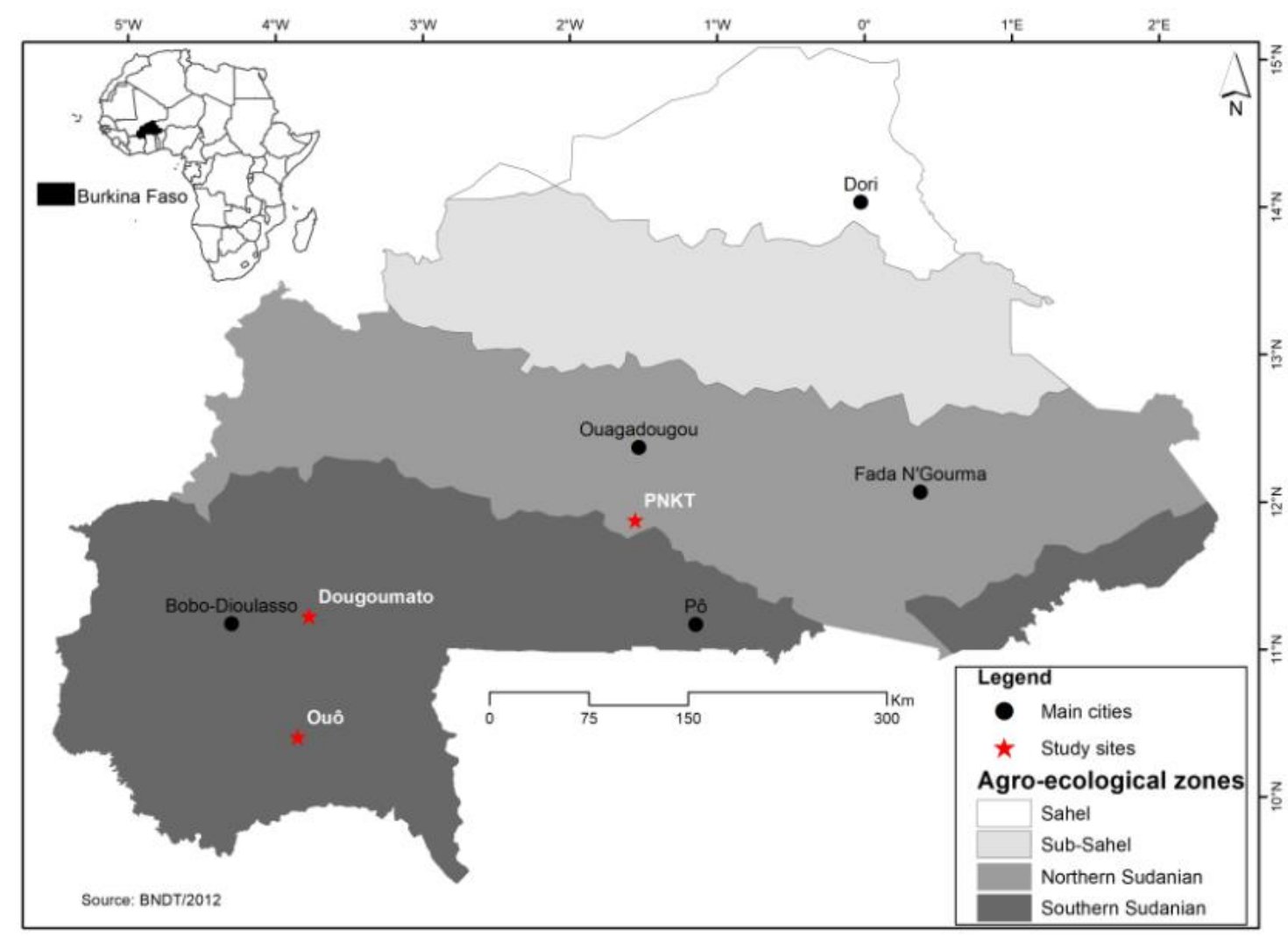

Figure 1. Location of the seeds collection sites 


\section{I Macrothink}

\section{Seed harvesting and Seed preparation}

Because the fruit of $F$. faginea is dehiscent, mature fruits were harvested before the seeds were dispersed by the mother plants. Harvesting took place from the $2^{\text {nd }}$ to the $25^{\text {th }}$ of April 2019 on a minimum of thirty (30) plants at each site. The phenology of the species is progressive, therefore, harvesting was done on the mother plants and respective dried fruits in a successive fashion. The harvested fruits were then packed in paper envelopes labelled with the date of harvest and origin of the plant). After each harvest, these fruits (photo 1) were stored in a dry place away from rodents and insects until the end of the harvest.

In the laboratory, the seeds were first prepared in batches according to site of origin. The pods were peeled to separate healthy seeds from impurities. Finally, using a magnifying glass, sorting was done and the healthy seeds were identified as those that were vigorous and without attack from insects.

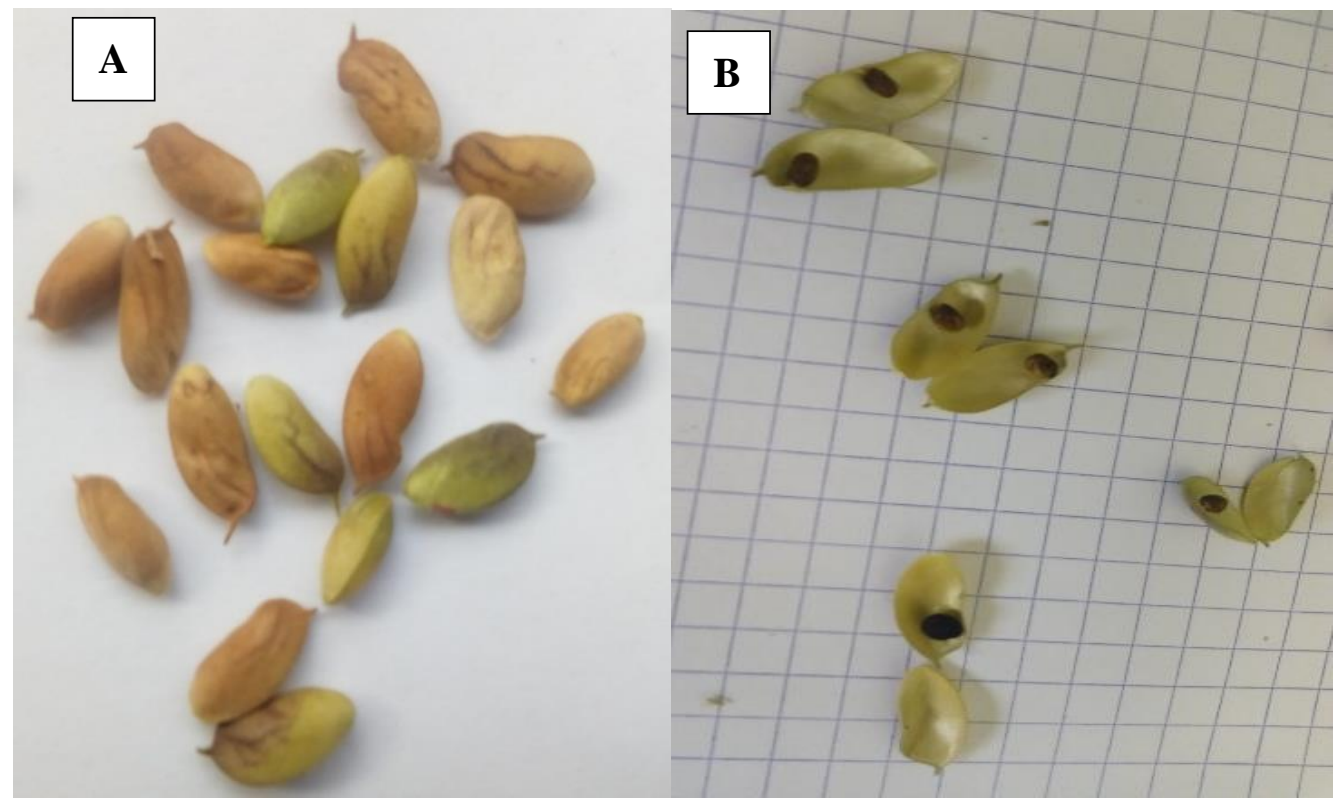

Photo 1. F. faginea fruits (A); Fruits with one or two seeds inside (B)

\section{Seed moisture content test}

The water content (TE) test was carried out on the $22^{\text {nd }}$ of May 2019 in accordance with ISTA rules of 2015. For the North Sudanian (NS) provenance, this was carried out in four (4) replicates with three (3) seeds per replicate; for the South Sudanian (SS) this was done in 4 replicates with ten (10) seeds per replicate. The variation in number of seeds per provenances was due to the limited number of seeds from the NS provenance.

This process first included weighing each dry empty cup ( $\left.\mathrm{P}^{\prime}\right)$ and followed by the same cup filled with fresh seeds (PF) (P").

The seeds were then dehydrated in an oven at $103^{\circ} \mathrm{C}$ for seventeen hours (17h). Following this, the seeds were cooled for 45 minutes by incubation in a desiccator containing silica gel to avoid. Repeat weighing was done on an electronic scale to obtain the weight of the dry 
seeds (PS).

The following formula was used to calculate the moisture content (MC) of the seed sample (ISTA, 2015):

MC $(\%)=($ Weight of Fresh seeds - Weight of Dry seeds $) /$ Weight of Fresh seeds $\times 100$

Where $\mathrm{MC}=$ moisture content of the seeds;

\section{Seed germination capacity}

\section{Pre-germination treatment}

For each provenance, dry seeds were randomly divided into three lots. Two of the three batches each underwent a different pre-germination treatment proposed by Baglo (1998) and Laouali et al., (2015) to remove seed dormancy whereas one lot was used as a control. Three seed treatments considered are presented in Table 1 below:

Table 1: Abbreviations and meaning of pre-germination treatments

\begin{tabular}{l|l}
\hline $\begin{array}{l}\text { Pre-germination } \\
\text { treatments } \\
\text { abbreviations }\end{array}$ & Meaning of the different pre-germination treatments \\
\hline T0 & $\begin{array}{l}\text { Control: Seeds which have not received any pre-germination } \\
\text { treatment }\end{array}$ \\
\hline T1 & $\begin{array}{l}\text { Soaking: Soaking the seeds in tap water at room temperature } \\
\text { for } 24 \text { hours. }\end{array}$ \\
\hline T2 & $\begin{array}{l}\text { Boiling: Soak the seeds in tap water boil at about } 100^{\circ} \mathrm{C} \text { and } \\
\text { leave to cool for } 24 \text { hours. }\end{array}$ \\
\hline
\end{tabular}

\section{Seed germination}

In May 2019, germination tests were carried out to test the viability and germination capacity of the seeds. Germination was carried out in Petri dishes of $10 \mathrm{~cm}$ in diameter containing sterilised cotton that served as a substrate to retain moisture (Photo 2). Each lot (T0, T1 and T2) from each provenance was repeated 4 times at a rate of 25 seeds per box (Kheloufi and Mansouri, 2017). The operation consisted in wetting the substrate contained in each Petri dish prior to laying out the 25 seeds and then closing the dish.

The conditions for germination were as follows:

the Petri dishes containing sowed seeds were laid out on a laboratory bench The neon bulbs in the room remained lit day and night during the test period to provide continuous white light to the seeds. During this period, the seeds were watered using tap water as needed to keep the substrate moist. 


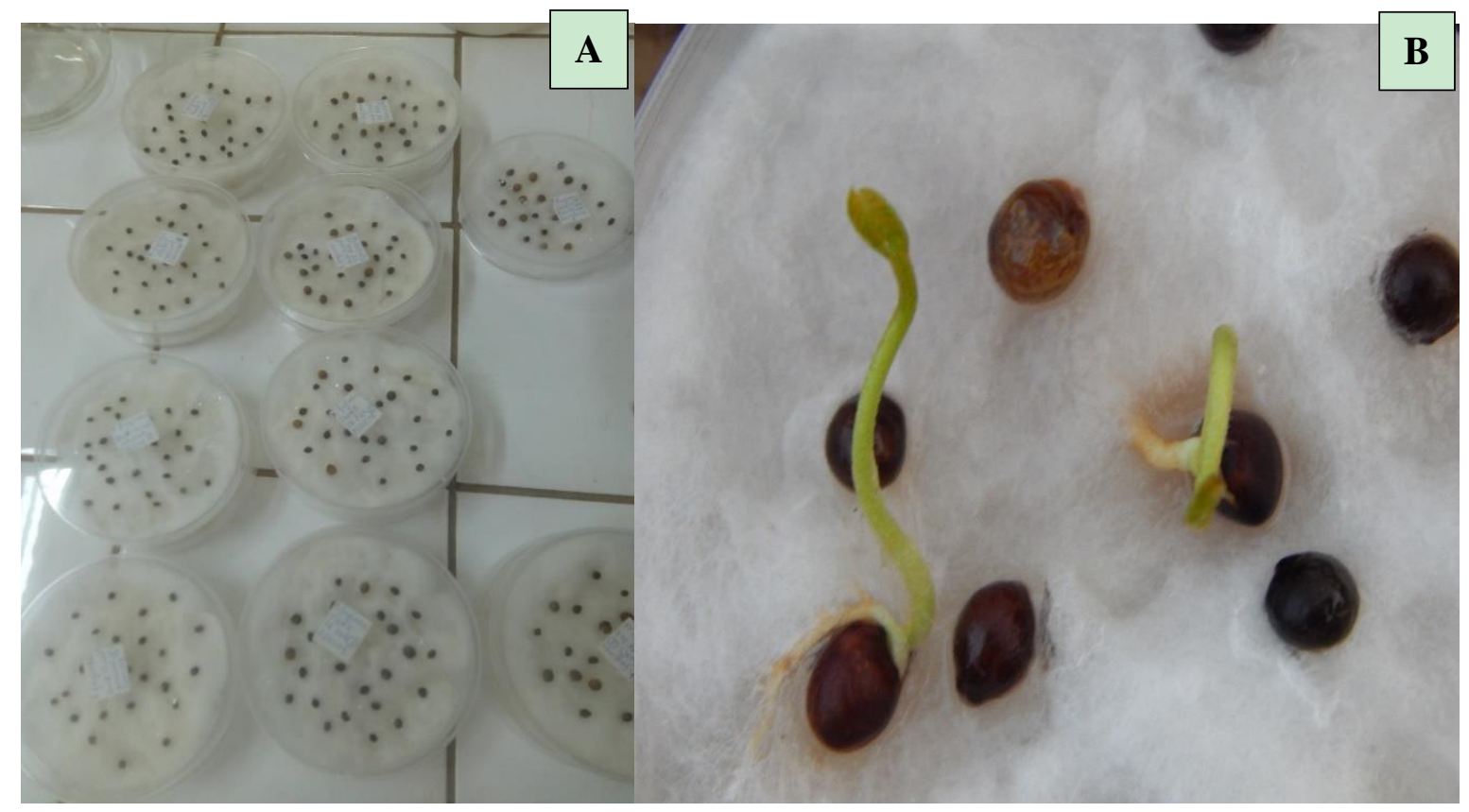

Photo 2. Seeds in Petri dishes (A) and seedling before transplanting (B)

The germination criterion selected was the emergence of the young rootlet out of the seed coat (Laouali et al., 2015). The number of germinating seeds was documented each day on a record sheet.

The following germination parameters were computed for each source:

The germination rate $(\mathrm{T})$ or germination capacity, i.e. the ability of the seeds to develop after being placed in favourable conditions for germination, was calculated formulas follows (Moupela et al., 2013):

$$
\mathrm{T}=\mathrm{G} \times 100 / \mathrm{N}
$$

Where

$\mathrm{G}=$ number of germinated seeds

$\mathrm{N}=$ number of seeds germinated per treatment.

The mean germination time (MGT) i.e. the time after which $50 \%$ of the seeds would have germinated seeds was calculated formulas follows (Berka and Harfouche,

2001):MGT $=\frac{\sum_{\mathbf{i}=1}^{\mathrm{n}}\left(\mathbf{n}_{\mathbf{i}} \times \mathbf{t}_{\mathbf{i}}\right)}{\mathbf{N}}$

With ni is the number of seeds germinated at time ti ( $\mathrm{i}$ ranging from 1 to $\mathrm{n}$ ) and $\mathrm{N}$ is the number of seeds germinated at the end of the test.

\section{Plant production in nursery}

Substrate composition 


\section{Macrothink}

A nursery substrate was used to evaluate seedling growth in a greenhouse. This substrate was obtained by homogeneously mixing three (3) volumes of soil, one (1) volume of sand and one (1) volume of manure and placing it in small pots $(250 \mathrm{~mm} \times 70 \mathrm{~mm})$. Following this, the substrate was graded and watered before transplanting began.

\section{Experimental transplanting device and seedlings transplantation}

The experimental device used was a complete randomized block with two repetitions by pre-processing for each source.

The transplanting took place from the $29^{\text {th }}$ of May 2019 to the $19^{\text {th }}$ of June 2019. As germination was spread out over time, transplanting was done on a daily basis as the seeds germinated in the laboratory. The transplanted seedling could only have developed a maximum of its' first two leaves. Thirty (30) seedlings per batch of treated seeds (T0, T1 and T2) from each provenance were transplanted into individual substrate pots. During the transplanting process, all dead seedlings were immediately replaced.

The transplantation process involved watering the substrate and then inserting a wooden stick in the middle of the substrate to create a hole for the seedling radicle. Single seedlings were taken from the box using a pair of pliers and placed in the cavities dug in the substrate. Finally, the hole was carefully filled and the soil was packed around the seedling (photo 3). In this way, the germinated seed was completely covered with soil if only the radicle alone had emerged. In the event it was a seedling, tits' leaves were left uncovered on the surface. Watering was done at the end of this process.

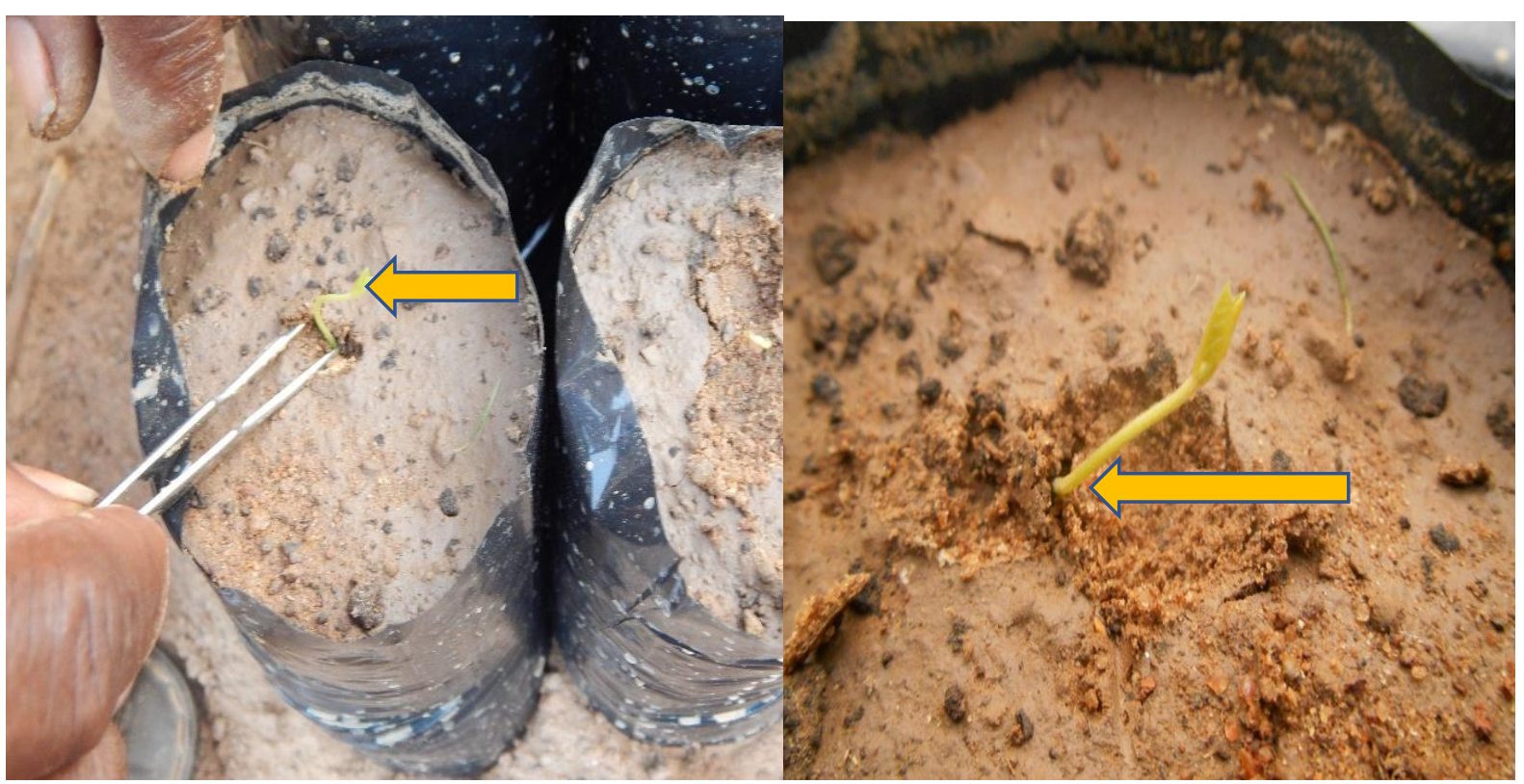

Photo 3. Seedling transplantation

Monitoring of seedling growth

The consisted mainly of:

- daily watering (morning) of seedlings in the event it did not rain; 
- clearing herbaceous in the pots and between plots to minimise herbaceous competition.

- Ensuring that the average environmental temperature and humidity were $29.38 \pm$ $2.24{ }^{\circ} \mathrm{C}$ and $68.74 \pm 6.40 \%$, respectively.

Measurements begun four (4) weeks following transplantation. These measurements were taken at weekly intervals for two months. The following parameters were measured for each seedling:

Growth and development parameters were measured as follows:

- diameter at the collar where the calliper was used to take the measurements;

- height of the seedlings was taken from the collar to the terminal bud of the stem

- leaves were counted from the base of the stem to the apical end. The number of branches.

The evolution of the survival rate ( $\mathrm{Sr}$ ) which shows the ability of the seedlings to survive throughout the observation period was calculated as follows (Moupela et al., 2013):

$$
\text { Sr }(\%)=\frac{\text { Number of live seedlings }}{\text { Initial number of transplanted seedlings }} \times \mathbf{1 0 0}
$$

\section{Data analysis}

The data were recorded using an Excel 2013 spreadsheet. Curves and graphs were plotted using MsExcel and various measures were calculated (germination rate, MGT). Minitab 2018 software was used for descriptive and variance analyses. A comparison of the mean values was then carried out by applying the Tukey test to the 5\% significant probability threshold using the same software.

\section{Results}

\section{Moisture content of seeds at harvest}

The initial moisture content (MC) was $9.03 \%$ for the South-Sudanian (SS) and $8.25 \%$ for the North-Sudanian (NS).

\section{Effects of pre-germination treatments on germination according to provenance}

The seeds from NS, the control treatment T0 had the highest germination rate (96\%). This was followed by soaking in tap water at room temperature for 24 hours (T1), which was $90 \%$ and the lowest rate was observed in the boiling water treatment (T2) which had a rate of 59\%.

For seeds from SS, T0 and T1 gave germination rates of $79 \%$ and $67 \%$, respectively. Whereas, $\mathrm{T} 2$ had the lowest germination rate of $49 \%$.

Effects of pre-germination treatments on latency and on the time between the first and the last germination 
For both provenances, the results show that germination of the three treatments of the NS provenance (T0, T1 and T2) started at the same time (two days after sowing) and then T0 takes precedence over the other two, T1 and T2. We can thus distinguish 3 phases, when the curves of the speed of germination is draw:

- A first phase of latency from 0 to 1 day, corresponding to the time of imbibition of the seeds.

- A second phase of acceleration of germination.

For the NS origin, acceleration of germination extended for 35 days (from the 2 nd to the 36 th day) for control seeds (T0); for 40 days (from the 2 nd to the 41 st day) for seeds soaked in water at room temperature (T1) and for 17 days (from the 2 nd to the 18th day for seeds soaked in boiling water (T2).

For the SS origin, the acceleration of germination extended for 46 days (from the 2 nd to 47 th day) for T0 i.e. control seeds and for T1 i.e. seeds soaked in water at room temperature for 24 hours). This was 44 days (day 2 to day 45) and 21 days (2 to day 22) for seeds soaked in boiling water (T2) are recorded from.

- A third phase characterised by a stage indicating a germination stop (stationary phase) of each pre-germination treatment.

Effects of pre-germination treatments and origin on the mean germination time (MGT)

The MGT expresses the time required for half (50\%) of the seeds to germinate (T50) (Table 1). The lowest MGT was observed from NS with T2 treatment, followed by NS with T0 treatment. T0 treatment for SS had a MGT of 14.09 days. T1 treatment for NS and SS provenances had a MGT of 14.47 and 17.63 days. T0 treatment for SS did not achieve a 50\% germination rate. 
Table 1. data on the rate of germination and the mean germination time

\begin{tabular}{|c|c|c|c|c|c|c|}
\hline \multirow[b]{2}{*}{ Treatment } & \multicolumn{3}{|c|}{ Germination rate $(\%)$} & \multicolumn{3}{|c|}{ Mean germination time (days) } \\
\hline & North-Sudanian & & uth-Sudanian & \multicolumn{2}{|c|}{ North-Sudanian } & South-Sudanian \\
\hline T0 & 96 & \multicolumn{2}{|r|}{79} & \multicolumn{2}{|c|}{9,28} & 14,09 \\
\hline $\mathrm{T} 1$ & 90 & & 67 & \multicolumn{2}{|c|}{14,47} & 17,63 \\
\hline $\mathrm{T} 2$ & 59 & & 49 & \multicolumn{2}{|c|}{7,25} & - \\
\hline Provenances & \multicolumn{2}{|c|}{ Treatments } & \multicolumn{2}{|c|}{ Germination rate } & \multicolumn{2}{|c|}{$\begin{array}{l}\text { Mean germination time } \\
\text { (days) }\end{array}$} \\
\hline \multirow[t]{3}{*}{ North-Sudanian } & \multicolumn{2}{|l|}{ T0 } & \multicolumn{2}{|l|}{$96 \%$} & \multicolumn{2}{|r|}{9,28} \\
\hline & \multicolumn{2}{|l|}{$\mathrm{T} 1$} & \multicolumn{2}{|l|}{$90 \%$} & \multicolumn{2}{|r|}{14,47} \\
\hline & \multicolumn{2}{|l|}{$\mathrm{T} 2$} & \multicolumn{2}{|l|}{$59 \%$} & \multicolumn{2}{|r|}{7,25} \\
\hline \multirow[t]{3}{*}{ South-Sudanian } & \multicolumn{2}{|l|}{ T0 } & \multicolumn{2}{|l|}{$79 \%$} & \multicolumn{2}{|r|}{14,09} \\
\hline & \multicolumn{2}{|l|}{$\mathrm{T} 1$} & \multicolumn{2}{|l|}{$67 \%$} & \multicolumn{2}{|r|}{17,63} \\
\hline & \multicolumn{2}{|l|}{$\mathrm{T} 2$} & \multicolumn{2}{|l|}{$49 \%$} & \multicolumn{2}{|r|}{-} \\
\hline
\end{tabular}

Effects of germination pre-germination treatments and provenance on seedling growth

Monitoring the height growth of seedlings in the nursery

In the NS provenance, the height growth of plants from T0 is slightly higher than that of the other two treatments. For SS provenance, plants from T0 and T2 have almost identical height growth, while those from T1 have the lowest height growth.

Concerning the analysis of variance, it revealed that the provenance had no significant influence on the height growth of the seedlings $(\mathrm{P}=0.684)$ at the $5 \%$ threshold. The mean height value shows that the plants from both provenances are identical for the Tukey test at the 5\% threshold (Table 2). In contrast to provenance, the effect of germ pre-germination treatment revealed a very highly significant difference $(\mathrm{P}=0.000)$ for height. Thus, the mean value for height shows that the plants in the control treatment (T0) are higher than T1 and T2, while $\mathrm{T} 1$ and $\mathrm{T} 2$ are identical to the Tukey test (Table 2) at the 5\% threshold. 


\section{I Macrothink}

Table 2. comparison of Tukey for height growth based on provenance and pre-germination treatment at the $5 \%$ threshold

\begin{tabular}{l|l|l}
\hline \multicolumn{2}{c|}{} & Mean \pm Standard deviation \\
\hline \multirow{2}{*}{ Provenances } & NS & $20.72 \pm 13.63 \mathrm{a}$ \\
\cline { 2 - 3 } & SS & $20.43 \pm 14.64 \mathrm{a}$ \\
\hline $\begin{array}{l}\text { Pre-germination } \\
\text { treatment }\end{array}$ & T0 & $22.62 \pm 14.53 \mathrm{a}$ \\
\cline { 2 - 3 } & T1 & $20.04 \pm 13.57 \mathrm{~b}$ \\
\cline { 2 - 3 } & T2 & $19.06 \pm 14.09 \mathrm{~b}$ \\
\hline
\end{tabular}

Averages that do not share any letters are significantly different

Diameter growth dynamics

The growth in diameter of the seedlings from the seeds from NS shows that the growth in diameter of $\mathrm{T} 0$ remained higher than the other two treatments during the period of the experiment. The plants from $\mathrm{T} 1$ and $\mathrm{T} 2$ seed had not significantly different average diameters during the first week, and from the second week until the end of the trial, the average diameter of T1 plants became larger and larger than that of T2. As for SS provenance, the average diameter of the plants from the $\mathrm{T} 0$ treatment remained larger during the experiment. It is followed, respectively by those of $\mathrm{T} 2$ and then $\mathrm{T} 1$.

Table 3. comparison of Tukey for diameter growth by provenance and pre-germination treatment at the $5 \%$ threshold

\begin{tabular}{l|l|l}
\hline \multicolumn{2}{l|}{} & Mean \pm Standard deviation \\
\hline \multirow{2}{*}{ Provenances } & NS & $2.56 \pm 1.01 \mathrm{a}$ \\
\cline { 2 - 3 } & SS & $2.35 \pm 1.11 \mathrm{~b}$ \\
\hline $\begin{array}{l}\text { Pre-germination } \\
\text { treatment }\end{array}$ & T0 & $2.68 \pm 0.93 \mathrm{a}$ \\
\cline { 2 - 3 } & T1 & $2.38 \pm 1.19 \mathrm{~b}$ \\
\cline { 2 - 3 } & T2 & $2.30 \pm 1.02 \mathrm{~b}$ \\
\hline
\end{tabular}

Averages that do not share any letters are significantly different

The analysis of variance showed that the effect of provenance on the growth in seedling diameter is significantly different $(\mathrm{P}=0.02)$. As for the ANOVA of the effect of the different pre-germination treatments on plant diameter growth, it was found to be highly significant $(\mathrm{P}=0.000)$. The mean diameter value in the Tukey test shows that $\mathrm{T} 0$ is greater than $\mathrm{T} 1$ and $\mathrm{T} 2$. While there is not significant different between T1 and T2 (Table 3). 


\section{1) Macrothink}

Leaves production

The results show that the plants from the three NS provenance treatments had approximately the same number of leaves during the monitoring period. In contrast, plants from SS provenance; T2 plants had the most leaves, followed by those from T0 and T1. This difference becomes greater towards the last weeks.

Table 4. Comparison of Tukey for leaf production based on provenance and pre-germination treatment at the $5 \%$ threshold

\begin{tabular}{l|l|l}
\hline \multicolumn{2}{l|}{} & Mean \pm Standard deviation \\
\hline \multirow{2}{*}{ Provenances } & NS & $11.599 \pm 6.10 \mathrm{a}$ \\
\cline { 2 - 3 } & SS & $9.781 \pm 5.23 \mathrm{~b}$ \\
\hline $\begin{array}{l}\text { Pre-germination } \\
\text { treatment }\end{array}$ & T0 & $11.167 \pm 5.43 \mathrm{a}$ \\
\cline { 2 - 3 } & T1 & $11.009 \pm 5.83 \mathrm{a}$ \\
\cline { 2 - 3 } & T2 & $9.894 \pm 5.92 \mathrm{~b}$ \\
\hline
\end{tabular}

Averages that do not share any letters are significantly different

With regard to ANOVA on leaf production, a highly significant difference $(\mathrm{P}=0,000)$ was revealed for each provenance. For the mean value of the leaves, the Tukey test for both provenances showed that the NS provenance produced more leaves than the SS provenance (Table 4). As for the germ pre-germination treatment effect on leaf production, the analysis of variance revealed a highly significant difference $(\mathrm{P}=0.000)$. Tukey's $5 \%$ threshold test (Table 4) for the mean leaf value shows that $\mathrm{T} 0$ and $\mathrm{T} 1$ are not significantly different. On the other hand $\mathrm{T} 2$ produces fewer leaves than $\mathrm{T} 0$ and $\mathrm{T} 1$.

Branching of the plants

For both origins, a very strong branching of the seedlings was observed. In fact, $64.44 \%$ of the seedlings from NS provenance branched compared to $53.33 \%$ from SS provenance. With regard to the level of positioning of the branching on the stem, $96.66 \%$ of seedlings from NS provenance branched at the basal position compared to $21.62 \%$ from SS provenance. 


\section{Macrothink Institute ${ }^{\mathrm{TM}}$}

Table 5. Comparison of Tukey for branching by provenance and pre-germination treatment at the $5 \%$ threshold

\begin{tabular}{l|l|l}
\hline \multicolumn{2}{l|}{} & Mean \pm Standard deviation \\
\hline \multirow{2}{*}{ Provenances } & NS & $0.47 \pm 0.89 \mathrm{a}$ \\
\cline { 2 - 3 } & SS & $0.30 \pm 0.82 \mathrm{~b}$ \\
\hline $\begin{array}{l}\text { Pre-germination } \\
\text { treatment }\end{array}$ & T0 & $0.47 \pm 1.00 \mathrm{a}$ \\
\cline { 2 - 3 } & T1 & $0.37 \pm 0.85 \mathrm{ab}$ \\
\cline { 2 - 3 } & T2 & $0.32 \pm 0.70 \mathrm{~b}$ \\
\hline
\end{tabular}

Averages that do not share any letters are significantly different

The analysis of variance carried out for the two provenances revealed a highly significant difference $(\mathrm{P}=0.000)$. Thus, the comparison of the mean values with the Tukey test (Table 5) at the $5 \%$ threshold revealed that the NS provenance produces more ramifications than the SS provenance. For seed pre-germination treatments, the effect on branching was found to be significant $(\mathrm{P}=0.016)$ at $5 \%$. The Tukey test at the 5\% threshold (Table 5) showed that $\mathrm{T} 2$ pre-germination treatment is superior to $\mathrm{T} 0$ and $\mathrm{T} 1$. Whereas $\mathrm{T} 1$ and $\mathrm{T} 0$ are not significantly different. Photo 4 shows an example of branching patterns for the seedlings during the test.

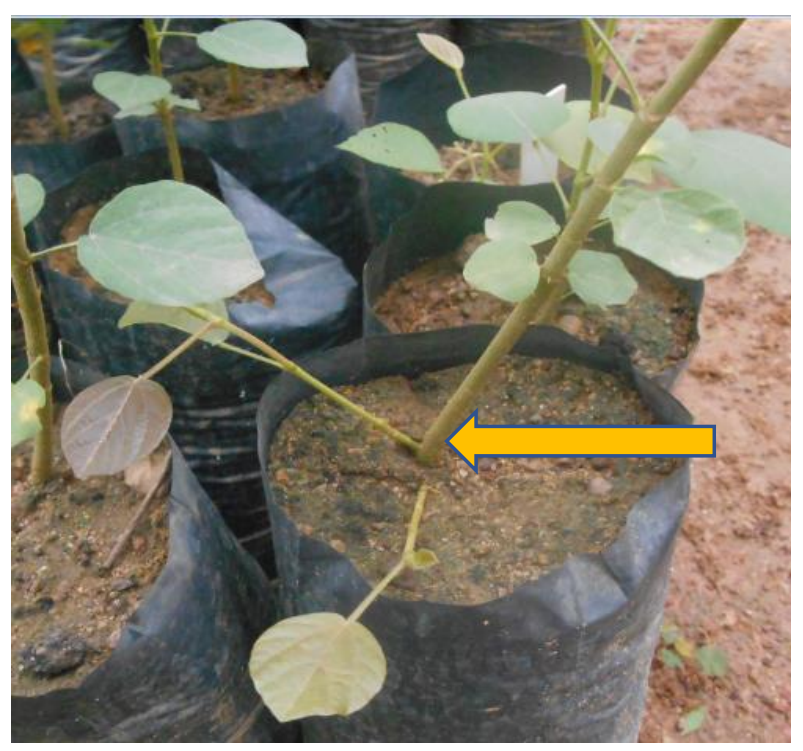

Photo 4. Branching patterns for the seedlings

Seedling survival rate

For both origins, we obtained $100 \%$ survival rate for T0. For the SS provenance, $100 \%$ of seeds soaked in boiling water (T2) survived while seeds soaked in ambient tap water (T1) gave had a survival rate of $83.33 \%$. For the NS provenance the survival rate of T1 and T2 were $96.66 \%$ and $93.33 \%$ respectively. 


\section{Discussion}

Seed maturation on mother tree usually ends with very strong dehydration. The moisture contents calculated for seeds from the two provenances was less than $10 \%$. This is enough to maintain viability during storage of orthodox seeds (Bonner, 2008). According to Dedi and Allou (2015), small seeds contain little water with slowed enzymatic reactions, so they can be stored well and therefore only need to be supplied with water for the slowed life to cease.

The study showed a variation in germination performance depending on the seed origin and the pre-germination treatments applied. The group of seeds that did not receive any pre-germination treatment (control, T0), had the highest germination capacity in each provenance (96\% for NS and $79 \%$ for SS) compared to the pre-germination treatments T1 and T2. This could be explained by the fact that seeds of $F$. faginea have a good germination capacity and therefore do not suffer from dormancy problems. Moreover, the fact that the seeds were not leached implies that the concentration of gibberellin would have be higher than that of abscisic acid. This, combined with the favourable environment tailored to improve the germination process may have led to the superior results obtained by T0 (Carvalho et al., 2016). Contrary to our results, studies on other legumes such as Parkia biglobosa Benth. (FAO, 1992). Pterocarpus erinaceus Poir (Bamba et al., 2018) and on Prosopis africana (Guill. \& Perr.) Taub. (Ahoton et al., 2009; Laouali et al., 2015) showed that pre-germination treatment is prerequisite to achieving high germination rates. Furthermore, these results confirm those of Houehounha et al., (2009) and also Djigbodjafe and Ouinsavi (2019) respectively on the germination of Daniellia oliveri (Rolfe) Hutchison and Dalziel and Abrus precatorius Linn. seeds.

The latency time (1 day) was short and did not differ by treatments used. Therefore, pre-germination treatments and provenance did not influence the latency time. These results contradict the work of Dardour et al., (2014) on Brachychiton acerifolius (Schott \& Endl.) R.Br. whose pre-germination treatments reduced the latency time. Seeds from the NS provenance were found to have the best performance in terms of latency, GMT and germination percentage compared to seeds from the south Sudanese (SS) provenance. These differences in germination rate between NS and SS provenance could be partly explained by the poor quality of some seeds from the SS provenance. Such results therefore suggest that seeds of NS provenance are preferable for the production of $F$. faginea plants in nurseries. Similar results were obtained by Yameogo (2018) with Securidaca longepedunculata Fres. and by Ado et al., (2017) with Diospyros mespiliformis Hochst. Ex A.DC which also showed a significant effect of provenance on seeds germination.

Germination takes 6-8 weeks for untreated (T0) and water-soaked seeds at room temperature. This germination staggering is thought to be due to differential dormancy (FAO, 1992; Moupela et al., 2013), a species' adaptation strategy to variations in rainfall (Ouedraogo, 2006). This survival strategy is relatively common in dense tropical rainforests (Moupela et $a l ., 2013)$. The treatment with tap water at room temperature obtained germination rates that were similar to that of the control. However, this pre-germination treatment did not reduce the MGT. The effect of soaking Brachychiton populneus in tap water has already been 
reported in the literature (Schott \& Endl.) and in general by Dardour et al., (2014) According to the FAO in 1992, soaking in water allows leaching of chemical inhibitors that are involved in physiological dormancy. As for boiling pre-germination treatment, the results give the fastest germination time and lowest rate of germination percentage and MGT than all other treatments. The lower MGT could be explained by the fact that boiling water causes cracks in the seed coat, allowing the seed to soften and sufficient water and oxygen to pass through the seed (Dardour et al., 2014), which accelerates germination. For T2, low germination rates are thought to be due to seed sensitivity to heat (Zerbo et al., 2010); or to germ asphyxiation (Dardour et al., 2014) caused by excess water entering the seed through cracks created by thermal shock. This results in the death of the embryo germ (Zerbo et al., 2010; Bamba et al., 2018). Similarly, according to Douma et al., (2019), the exposure of a seed that is not dormant to high temperature for a long period has a lethal effect on it. This may explain the low germination rates obtained by $\mathrm{T} 2$.

However, the same pre-germination treatment has been shown to improve germination of seeds of other species such as of Parkia biglobosa (FAO, 1992) and Prosopis africana (Ahoton et al., 2009). According to Ahoton et al., (2009), the length of time seeds are soaked in boiling water depends on the thickness and hardness of the seed coat. Using boling water is preferable for thicker and harder seeds coat (Gama-Arachchige et al., 2013b). Overall, the most effective treatment to trigger the germination process of $F$. faginea was the T0 control test.

As regards the morphological development of $F$. faginea in the nursery, results of the ANOVA test comparing pre-germination treatments revealed differences in growth parameters depending on the origin of the seeds for all parameters except the seedling height. The NS provenance recorded the best growth in diameter, branching and leaves production. These differences could partly be explained by a lack of adaptation of the seedlings of the SS provenance in the NS zone leading the seedlings to behave differently. The SS zone is a high rainfall area and the species probably acquired the ability to minimize diametric growth, leaf and branch production; and to grow faster in height, in competition with other species for environmental factors. Tandjiékpon and Dah-Dovononon (1999) and Kafando (2016) also found a significant effect of provenance on the growth of seedlings of Acacia auriculiformis A. Cunn. ex Benth. and Prosopis Africana, respectively. Results of ANOVA also illustrated that the growth performance of the seedlings matched their germination trend.

The average stem height, diameter and number of leaves values of $\mathrm{T} 0$ were higher than $\mathrm{T} 1$ and $\mathrm{T} 2$. This indicates that growth hormones were leached out by soaking in water (T1 and T2) and more concentrated in the seedlings from untreated seeds. These results are in opposition with those obtained by other authors (Douma et al., 2019; Djigbodjafe and Ouinsavi, 2019; Lompo et al., 2019), who showing that seed pre-germination treatment is needed to stimulate growth initial of the seedlings. Similarly, N'Danikou et al., (2014) pointed out that even if a seed quality has been sown on fertile soil with water supply, the vigour of the seedling will be affected by the time taken by the seed to germinate. In this case, the seed embryo is weakened over time if germination takes longer time than normal. The growth of the seedlings in the nursery was very fast. This would probably be due to the 
favourable temperature $\left(29.38^{\circ} \mathrm{C}\right)$ and humidity $(68.74 \%)$, the substrates provided and the production period of the plants. These results support those of Nguema et al., (2013) who found similar results on Jatropha curcas showing that seed regeneration of the plants shows rapid growth.

As regards the survival rate of seedlings in F. faginea nurseries, the control treatment (T0) superseded other pre-germination treatments. However, the leaves of some plants were probably attacked by insects. Generally, for most of the local plant species in Burkina Faso, seedlings produced in the nursery range from 15 to $30 \mathrm{~cm}$ in height. Therefore, after two to three months of growing in the nursery, seedlings obtained by sexual reproduction can be planted in the fields.

\section{Conclusion}

The present study provided information on the reproductive capacity and growth different seeds of Flemingia faginea from Burkina Faso. Based on these results, the sustenance of $F$. faginea is possible through seed propagation.

The germination characteristics of $F$. faginea seeds showed that its' seeds are not dormant. The untreated (control) seeds had the best germination capacity and the best potential in growth and survival. The North-Sudanian provenance was the preferred area for seed collection for optimal germination capacity and growth with plant vigour and good branching.

\section{References}

Ado, A., Bil-Assanou, I. H., Iro, D. G., Toudou, D. A. G., Ali, M., \& Mahamane, S. (2017). Effet de prétraitements. de substrats et de stress hydriques sur la germination et la croissance initial de Diospyrios mespiliformis Hochst. Ex A. DC. European Scientific Journal, 13(21), 251-268. https://doi.org/10.19044/esj.2017.v13n21p231

Ahoton, L., Adjakpa, E., M'po, I. M., \& Akpo, E. L. (2009). Effet des prétraitements des semences sur la germination de Prosopis africana (Guill., Perrot. et Rich.) Taub (Césalpiniacées). Tropicultura, 27(4), 233-238.

Baglo, A. M. (1998). Guide pratique d'implantation de pépinières villageoises au Benin. Agence béninoise pour l'environnement (ABE) 349p

Bamba, N'G., Ouattara, N. D., Konan, D., Bakayoko, A., \& Tra, B. I. F. H. (2018). Effets de cinq prétraitements sur la germination du vène (Pterocarpus erinaceus Poir., Fabaceae) dans la Réserve du Haut Bandama (Côte d'Ivoire). European Scientific Journal, 14(30), 438. https://doi.org/10.19044/esj.2018.v14n30p438

Bélem, B., \& Nana-Sanon, P. (2009). Plantes médicinales utilisées pour le soin des enfants dans la ville de Ouagadougou, Burkina Faso, Afrique de 1'Ouest. Le Flamboyant, 65, 9-12.

Bélemtougri, R. G., Dzamitika, S. A., Ouédraogo, Y., \& Sawadogo, L. (2007). Effects of water crude leaf extract of Sclerocarya birrea (A. Rich.) Hochst. (Anacardiaceae) on normotensive rat blood pressure. Journal of Biological Sciences, 7(3), 570-574. https://doi.org/10.3923/jbs.2007.570.574 
Berka, S. \& Harfouche, A. (2001). Effets de quelques traitements physico-chimiques et de la température sur la faculté germinative de la graine d'Arganier. Rev. For. Fr., (2), 5-10. https://doi.org/10.4267/2042/5219

Bonner, F. T. (2008). The woody plant seed manual. Washington: Government Printing Office. $1223 p$.

Carvalho, T. C., Ohlson, O. D. C., \& Panobianco, M. (2016). Alternative treatment to stimulate the germination of recently harvested wheat seeds. Journal of Seed Science, 38(4), 344-349. https://doi.org/10.1590/2317-1545v38n4166272

Cissé, A., Gueye, M., Ka, A., Ndiaye, F., Koma, S. \& Akpo, L. (2016). Ethnobotanique des plantes médicinales chez les bergers peuls de Widou Thiengoly de la commune de Téssékéré (Ferlo-Nord Sénégal). Journal of Applied Biosciences, 98, 9301-9308. https://doi.org/10.4314/jab.v98i1.6

Compaoré, M., Meda, R. N. T., Zerbo, P., Karama, I., Traore, O., Lamien-Meda, A., ... Novak, J. (2018). Availability Evaluation of Twelve Antimalarial Medicinal Plants from Western Regions of Burkina Faso. Journal of Diseases and Medicinal Plants, 4(3), 80-88. https://doi.org/10.11648/j.jdmp.20180403.13

Dardour, M., Daroui, E. A., Boukroute, A., Kouddane, N. E., \& Berrichi A. (2014). Etude de prétraitements des graines de Brachychiton populneus (Schott \& Endl.) R.Br. et B. acerifolius F.Muell. en faveur de leur germination (Study of pretreatment seeds Brachychiton populneus (Schott \& Endl.) R.Br. and B. acerifolius F.Muell. for germination). J. Mater. Environ. Sci., $5(6)$.

Dedi, K., \& Allou, K. (2015). Etude du pouvoir germinatif de quatre variétés de riz que sont GIZA 178, WAB 56-50, LOHININI, DANANE et identification des champignons sur les grains en germination. Afrique Sciences, 11(3), 161-171.

Dembelé, I. (1988). Tradipraticien et les soins de santés primaires. Thèse de doctorat national de médecine. Université nationale de Côte d'Ivoire. 268p.

Djigbodjafe, D. B., \& Ouinsavi, C. (2019). Test de germination des graines de Abrus precatorius Linn au Bénin. Journal of Applied Biosciences, 142, 14540-14550

Douma, S., Adamou, M. M., Aboubacar, K., Alleidi, I., \& Boubacar, A. (2019). Effet du régime d'irrigation sur la germination et la croissance en pépinière de Parkia biglobosa (Jacq.) G. Don. Journal of Animal \& Plant Sciences, 40(1), 6573-6583. http://www.m.elewa.org/JAPS

FAO., (1992). Guide de manipulation des semences forestières. Organisation des Nations Unies pour l'Alimentation et l'Agriculture. Rome. ISBN 92-5-202291-0.

Fontès, J., \& Guinko, S. (1995). Carte de la végétation et de l'occupation du sol du Burkina Faso. Note explicative. Ministère de la Coopération Francaise, Toulouse, France, 67p.

Gama-Arachchige, N. S., Baskin, J. M., Geneve, R. L., \& Baskin, C. C. (2013b). Identification and characterization of ten new water gaps in seeds and fruits with physical dormancy and classification of water-gap complexes. Annals of Botany, 112, 69-84. 
https://doi.org/10.1093/aob/mct094

Houehounha, R., Avohou, H. T., Sinsin, B., \& Tandjiekpon, A. M. (2009). Approches de régénération artificielle de Daniellia oliveri (Rolfe) Hutchison et Dalziel. Int. J. Biol. Chem. Sci., 3(1), 7-19. https://doi.org/10.4314/ijbcs.v3i1.42730

ISTA. (2015). International Rules for Seed Testing. 2015 ed. Bassersdorf: ISTA. 276p.

Kafando, W. K. A. C. B. I. (2016). Etude des caractéristiques morphologiques des graines et des paramètres de croissance de Prosopis africana (Guill. \& Perr) Taub. en pépinière de vingt provenances de trois pays sahéliens Ouest africains. Mémoire d'Ingénieur du Développement Rural: Eaux et Forêts. Université polytechnique de Bobo Dioulasso. Burkina Faso. 60p

Kheloufi, A., \& Mansouri, L. M. (2017). Effet de l'acide sulfurique sur la germination d'un arbre fourrager Acacia nilotica (L.) subsp tomentosa. Livestock Research for Rural Development, 29(2).

Koadima, M. (2008). Inventaire des espèces ligneuses utilitaires du Parc W et terroirs riverains du Burkina Faso et état des populations de trois espèces à grande valeur socio-économique. Mémoire de DEA. Université de Ouagadougou. Laboratoire de Biol. et Ecol. Végét.56 p.

Konaté, K., Ouattara, N., Arsène, M., Souza, A., Oksana Sytar, O., Brestic, M., \& Dicko, H. M. (2018). Anti-Nociceptive and Anti-Inflammatory Properties of Polyphenol-Rich Fractions of Roots from Ximenia americana L., (Olacaceae), in Experimental Mice. International journal of pharmacy and pharmaceutical research, 12(1).

Laouali, A., Rabiou, H., Abdoullatif, Y. T., Iro, D. G., \& Ali, M. (2015). Etude de la germination de la graine et suivi de la croissance en pépinière de Prosopis africana (G. et Perr.) Taub., espèce menacée de disparition au Niger. Annales de l'Université Abdou Moumouni de Niamey. Tome XVIII-A. 1-12.

Lompo, O., Dimobe, K., Lankoande, B., \& Ouedraogo, A. (2019). Performances germinatives des graines de Lannea microcarpa Engl. \& K. Krause (Anacardiaceae) de provenance sahélo-soudanienne du Burkina Faso. Tropicultura, 37(3).

Millogo-Koné, H., Guissou, I. P., Nacoulma-Ouédraogo, O., \& Traoré, A. S. (2007). Study of the antibacterial activity of the stem bark and leaf extracts of Parkia biglobosa (Jacq.) Benth on Staphylococcus aureus. African Journal of Traditional, Complementary and Alternative Medicines, 3(2), 74-78. https://doi.org/10.4314/ajtcam.v3i2.31159

Moupela, C., Doucet, J. L., Daïnou, K., Meunier, Q., \& Vermeulen, C. (2013). Essais de propagation par semis et marcottage aérien de Coula edulis Baill. et perspectives pour sa domestication. Bois et forêts des tropiques, 318(4), 3-13. https://doi.org/10.19182/bft2013.318.a20516

N'danikou, S., Achigan-Dako, E. G., Tchokponhoue, D. A., Assogba, F. K., Gebauer, J., Vodouhe, R. S., \& Ahanchede, A. (2014). Enhancing germination and seedling growth in Vitex doniana Sweet for horticultural prospects and conservation of genetic resources. Cirad/EDP Sciences, 69(4), 279-291. https://doi.org/10.1051/fruits/2014017 
Nguema Ndoutoumou, P., Bouanga, E. B., Massounga, Y. C., \& Boussiengui Boussiengu, G. (2013). Étude comparée de trois méthodes de multiplication de Jatropha curcas L. dans les conditions climatiques du sud-est du Gabon. Journal of Applied Biosciences, 65, 4989-4998. https://doi.org/10.4314/jab.v65i0.89641

Ouattara, N., Ramdé-Tiendrébeogo, A., Guenné, S., Sumera, Z., Meda, N. T. R., Konaté, K., ... Kiendrébeogo M. (2019). Cytotoxicity Potential of Nelsonia canescens (Lam.) Spreng Extracts against Cervical Cancer Cell Lines. Saudi Journal of Biomedical Research. ISSN 2518-3214 (Print) |ISSN 2518-3222 (Online

Ouattara-Danté, S., Ouédraogo, S., Lompo, M., Somé, N., \& Guissou, I. P. (2003). Études pharmacologiques du macéré aqueux des écorces de racines de Faca xantylö̈des Lam. (Rubiaceae) utilisées en phytothérapie de la maladie drépanocytaire au Burkina Faso. Revue Sciences et Techniques, série Sciences de la Santé, 26(1), 75-84.

Ouédraogo, A. (2006). Diversité et dynamique de la végétation ligneuse de la partie orientale du Burkina Faso. Thèse de Doctorat $3^{\text {ème }}$ cycle. Université de Ouagadougou. Burkina Faso. 230p.

Ouoba, P., Lykke, A. M., Boussim, J., \& Guinko, S. (2006). La flore médicinale de la forêt classée de Niangoloko (Burkina Faso). Études sur la Flore et la Végétation du Burkina Faso et des pays environnants. 10, 5-12. https://doi.org/10.1051/fruits:2006006

Tandjiékpon, A. M., \& Dah-Dovonon, J. Z. (1999). Influence de la provenance des semences forestières sur le développement des plants en pépinière: cas d'Acacia auriculiformis A. Cunn. ex Benth. Bulletin de la Recherche Agronomique. p 22-31.

Traoré, L., Ouédraogo, I., Ouédraogo, A., \& Thiombiano, A. (2011). Perceptions, usages et vulnérabilité des ressources végétales ligneuses dans le Sud-Ouest du Burkina Faso. Int. J. Biol. Chem. Sci., 5(1), 258-278. https://doi.org/10.4314/ijbcs.v5i1.68103

Yameogo, B., (2018). Détermination de techniques d'amélioration de la production de Securidaca longepedunculata Fres. En pépinière. Mémoire d'ingénieur du développement rural (eaux et forêts). Université NAZI BONI. Burkina Faso. 78p.

Zerbo, P., Belem, B., Millogo-Rasolodimby, J., \& Van Damme, P. (2010). Germination sexuée et croissance précoce de Ozoroa insignis Del., une espèce médicinale du Burkina Faso Cameroun. Journal of Experimental Biology, 06(02), 74-80. https://doi.org/10.4314/cajeb.v6i2.68524

Zerbo, P., Millogo-Rasolodimby, J., Nacoulma-Ouedraogo, O. G., \& Damme, P. V. (2011). Plantes médicinales et pratiques médicales au Burkina Faso: cas des Sanan. Cameroon Journal of Experimental Biology, 307(1), 41-53. https://doi.org/10.19182/bft2011.307.a20481

\section{Copyright Disclaimer}

Copyright for this article is retained by the author(s), with first publication rights granted to the journal.

This is an open-access article distributed under the terms and conditions of the Creative Commons Attribution license (http://creativecommons.org/licenses/by/4.0/). 